This is a self-archived version of an original article. This version may differ from the original in pagination and typographic details.

Author(s): Tikkanen, Tarja; Nissinen, Kari

Title: Drivers of job-related learning among low-educated employees in the Nordic countries

Year: 2018

Version: Accepted version (Final draft)

Copyright: (c) 2018 Taylor \& Francis

Rights: In Copyright

Rights url: http://rightsstatements.org/page//nC/1.0/?language=en

Please cite the original version:

Tikkanen, T., \& Nissinen, K. (2018). Drivers of job-related learning among low-educated employees in the Nordic countries. International Journal of Lifelong Education, 37(5), 615-632. https://doi.org/10.1080/02601370.2018.1554720 


\section{Drivers of job-related learning among low-educated employees in the Nordic countries}

This study explored drivers of participation in job-related lifelong learning (LLL) among low-educated mature-aged employees and compared them across four Nordic countries. Workplaces can be low-threshold, effective arenas for development of their skills in work and learning. The paper builds on the Bounded Agency Model and theories of learning motivation, human capital, and workplace learning. We used data from the Survey of Adult Skills (PIAAC) by OECD. The average participation rate was $36 \%$. Results of the logistic regression analyses showed that income, skills use at work, sector and gender were significant drivers of participation in all countries. Additionally, being under-skilled was significant in Finland and parents' education in Sweden. Totally, these variables explained a quarter of the variation in participation. Thus, the drivers of participation appeared more similar than different across the countries. Implications of the findings are discussed in relation to how to support skills development among low-educated older workers, and to some challenges in crosscountry comparative research.

Keywords: job-related learning, participation, low-educated, mature employees, Nordic countries, PIAAC 


\section{Introduction}

The purpose of the study is to explore participation in job-related, organised lifelong learning $(\mathrm{LLL})^{1}$ among low-educated, middle-aged (45-65-year-old) employees in the Nordic countries. Thus, thematically the study is related to three broader discussions. The first is the call for continuous development of job skills, and not only in technology-intensive work (Ref. removed for anonymity), to better meet the demands for new and renewing skills, and to tackle the risk of growing skills mismatch on the labour market (Cedefop, 2015; 2018). Second, the ageing population has significant implications on the labour force with simultaneously falling labour supply and increasing demand for labour force participation (European Commission, 2018). Third, there has been a growing international interest in the Nordic model in general (e.g. Booth, 2014; Hodgson, 2018; Iqbal \& Todi, 2015) and the Nordic model of education and lifelong learning in particular (Antikainen, 2010; Blossing, Imsen \& Moos, 2014; NordForsk, 2017; Rubenson, 2006) - a model that at the same time is facing challenges of its own (Andreasson, 2018).

When it comes to lifelong learning, older, low-educated employees, often with learning-poor jobs, may find themselves in double jeopardy in current workplaces. On the one hand, their job skills may have eroded, in addition to the atrophy of their learning skills due to non-use (DeGrip \& Van Loo, 2002; Roosmaa \& Saar, 2017). On the other hand, they may be offered fewer learning opportunities because of their age and/or show little interest in participation in formal adult education (Vono de Vilhena et al., 2014; Zanazzi, 2018). Employees' individual skills needs and skills maintenance have their counterpart in their jobs and workplaces. It is in the interplay between the quality of jobs on the one hand, and the qualities and qualifications of workers on the other hand that learning at work takes place.

\footnotetext{
${ }^{1}$ While the conceptualizations of LLL vary across countries, most definitions build on the view promoted by major international organisations, UNESCO and the OECD and the European Union (UNESCO, 2016a), acknowledging that the concept of LLL covers all ages, all levels of education and all modalities of learning (formal, informal, non-formal), in all life contexts.
} 
Both of these sides can be "low-skilled", as pointed out by Cort, Mariager-Anderson and Thomsen (2018) in their Danish study "busting the myths of low-skilled workers".

Nevertheless, most job-related learning takes place in the context of work (DeFilippi \& Arthur, 1994), and most lifelong learning is job-related (Desjardins, 2015). Consequently, workplaces can be important, low-threshold learning arenas for older employees as well, where access to learning, at least in principle, should not be limited because of bias towards employees, for example, based on demographics or prior education (e.g., Boeren, Nicaise \& Baert, 2010; Desjardins, 2015; Massing \& Gauly, 2017). Indeed, studies (e.g., Mellander \& Fremming Anderssen, 2015; Ref. removed for anonymity) show that in the Nordic countries, participation rates tend to be high among low-skilled, older adults as well.

The lack of internationally comparative knowledge is due to lack of available highquality data making such comparisons possible. We use data from the Survey of Adult Skills (later referred to as PIAAC) by the Organisation for Economic Co-operation and Development (OECD). PIAAC is carried out in approximately 40 countries, being one of the largest studies, in depth and scope, of adult skills and competence. It provides unique, highquality international data on cognitive and workplace skills of individuals of working age, as well as extensive background data on the individuals' education and career. Thus, it is wellsuited for the purpose of our study, too. A recent review (Ref. removed for anonymity) showed that PIAAC seems to have increased researchers' interest in internationally comparative studies on lifelong learning. Our comparisons only cover the four Nordic countries that participated in PIAAC in the first round: Denmark, Finland, Norway and Sweden. Participation in LLL in these countries has several similarities, as we will discuss later in this article. However, there is little comparative knowledge across these countries on the similarities or differences between the factors driving participation among low-educated older adults - an area where we seek to contribute new knowledge. 
We have fixed the level of education to only low-educated (max. ISCED 3c, see OECD, 2013) in this study. However, in most studies of participation, the highest completed education is typically used as an independent variable. As such, it commonly explains most of the variation in participation in LLL, universally - also described as accumulation hypothesis (Tuijnman, 1991) or Matthew-effect (Vono de Vilhena, et al., 2014). A study exploring the impact of country-level and individual characteristics on adults' participation in Europe (Dämmrich, Vono de Vilhena \& Reichart, 2014) found that education is seemingly "the most important influencing factor for participation" in both formal and non-formal learning activities, across all the five country clusters investigated. By fixing education level, we aim to advance our understanding on drivers of participation in the Nordic countries beyond the education accumulation hypothesis.

We have concentrated on participation in organized forms of learning, i.e., formal or non-formal job-related LLL. Thus, informal learning, albeit meaningful, is beyond the interest of this study. In PIAAC, the reference period of 12 months preceding the survey is used to measure participation in formal and non-formal LLL. It follows that prior education background is not included in and obscuring the outcome measure (none of the respondents in the study had completed a degree within the reference period).

The study is structured into five main sections. After presenting the research questions, we describe our theoretical frame of reference and the Nordic setting for participation in LLL. The third section presents the research methodology, followed by the findings. In the final section we discuss the findings against the theoretical and Nordic framework, with implications for how to support skills development among low-educated older workers.

\section{Research questions}

This study seeks to answer to the following research questions: 
1. To what extent do demographic, individual, job-related characteristics and skills use at work explain participation in job-related learning among low-educated, mature adults?

2. To what extent are the above effects different across the four Nordic countries, if any?

On the side of being cross-nationally comparative, our research approach is interdisciplinary. While adult education theories have shown that individual factors (e.g., motivation) are crucial for LLL participation (e.g., Sandlin, White \& Clark, 2011), human resources development theories have underlined the importance of factors related to jobs, work organisations, as well as occupational branches and sectors (Swanson, 2001; Ref. removed for anonymity). We have also included skills use at work as a potential driver of participation. PIAAC has brought attention to the widespread skills underutilization at work, calling for the studies of skills development to expand their focus on skills needs (Desjardins \& Warnke, 2012).

\section{Theoretical frame of reference}

\section{The bounded agency model}

It was almost 10 years ago that Rubenson and Desjardins (2009) pointed out how there had been little theoretical development on adults' participation in learning since Cross (1981) presented the classification of dispositional, situational and institutional barriers to participation. They proposed a new theory, Bounded Agency Model (BAM), which expanded the predominant focus on an individual perspective to incorporate the "broader structural conditions and targeted policy measures, and analyse the interaction between these and the individual's conceptual apparatus" (Rubenson \& Desjardins, 2009, p. 195). Building further on Esping-Andersen's (1989) conceptualization of welfare state regimes, Rubenson and Desjardins (2009) proposed that 
"the welfare state regime can affect a person's capability to participate through the way it constructs the material, social and institutional environments and the way these result in situational and institutional, or structural barriers as well as a person's internal state of readiness as expressed in dispositional barriers" (ibid. p. 197).

Participation research has typically emphasized the active, "agentic" role of the learners (e.g., Billett, 2001; Engeström, 2001; Hodginson \& Hodginson, 2003). The BAM suggested that an individual agency to freely choose to participate could be bound by structural conditions. Not only are the circumstances (faced by individuals and the feasible alternatives to choose from) dependent on structural and socio-economic conditions, but they also affect - directly and indirectly - individual dispositions and preferences, i.e., how a person acts, thinks, and orients him- or herself to the social world (ibid. p. 196-197). Thus, the BAM suggested that participation is not as voluntary an act for a person to choose, as it is often regarded.

The BAM is frequently used in comparative studies to explain participation, in particular after the PIAAC data was made available. As PIAAC not only provides unique data on adult skills and competences, but also covers a large number of countries, it makes reliable cross-national comparisons possible. The PIAAC data also provides a sound foundation for our explorative comparisons between the four Nordic countries, applying the perspective of the BAM. Indeed, a recent wave of research (Boeren, 2017; Boeren \& Holford, 2016; Lavrijsen \& Nicaise, 2017; Massing \& Gauly, 2017; Rothes, Lemos \& Goncalves, 2017) calls for the importance of understanding the role of structural factors and institutional settings of the country or countries in question, also in case of low-skilled (Brown \& Bimrose, 2018; Zanazzi, 2018) and non-participants (Becker Patterson, 2018; Roosmaa \& Saar, 2017). The study by Boeren Holford (2016) found that the worker's country explained participation even stronger than individual characteristics (e.g., age, gender, education and occupation). 
We have limited the scope of comparisons in our study to four Nordic countries Denmark, Finland, Norway and Sweden - on the one hand because of the apparent homogeneity of these Nordic welfare state regime countries (Rubenson \& Desjardins, 2009), in terms of the institutional setting, their political, socio-cultural and historical context and development (Iqbal \& Todi, 2015). Furthermore, another reason why we have chosen the BAM to explore participation of the low-educated mature-aged employees is that the Nordic welfare state regime has particular characteristics, which, as described by Rubenson and Desjardins (2009), have "profound effects" on barriers to and, thus, adults' participation in lifelong learning. First, the full employment concept is a founding pillar of the Nordic welfare strategy, with strong links between employment and education policies. Second, industrial relations are anchored in a highly developed corporatist structure, with negotiations between state, employers and unions. The latter have also incorporated adult education issues, for example, related to new technology and work organization. Third, there is also a statesupported adult education provision in the domain of civic society, making lifelong learning affordable and accessible to all citizens. Fourth, the emphasis on equity has strong impact on funding regimes. Adult education is seen as a part of a broader social agenda (ibid. p. 198). Rubenson and Desjardins (2009) suggest that the provision of targeted measures to disadvantaged groups may partly explain the comparatively higher participation rates in the Nordic countries among unemployed, immigrants, older adults, low-educated, and low-skilled adults (ibid. 198).

More recent research has shown that the targeted support to adult learning has been successful in terms of higher participation rates among low-educated workers, in comparison to other welfare regimes (Lavrijsen \& Nicaise, 2017; Roosamaa \& Saar, 2017; Ref. removed for anonymity), albeit with no guarantee for higher participation by disadvantaged groups or a decrease in social inequality (Vono de Vilhena, et al., 2014). Perhaps not surprisingly, the 
Nordic region has been pointed out as one with the most developed and well-functioning adult education system in Europe (Vinther-Jørgensen, et al., 2013), and with one of the best provisions of both job-related and non-job-related adult education opportunities among OECD countries (Desjardins, 2015).

\section{The Nordic setting for participation in $L L L$}

Participation of adults in LLL is high in the Nordic countries, relatively speaking, as well as among low-skilled workers and those in older age groups (Mellander \& Fremming Andressen, 2015; Mellander, Fremming Andressen \& Sønnesyn, 2015; Ref. removed for anonymity). Figure 1 shows an example of the latter in regards to formal and non-formal LLL between the EU average and the Nordic countries; it also presents trends during the last decade. The figure is based on a population of employees aged 55-74 years, of all educational levels, as Eurostat (2018) does not provide data on exactly our target group. The Eurostat (2018) period of reference for measuring LLL is the last four weeks prior to the survey interview (based on the Labour Force Survey).

[Figure 1. Approximately here]

Throughout the 10-year period, the participation rates in the Nordic countries have been much higher than the EU average, albeit with level and trend differences across them (Figure 1). The trend has been increasing in Sweden and Finland during the last decade, while it has taken a downward turn in the other three Nordic countries around 2015. In 2017, these rates were from 1.8 to 2.8 times higher for this population in the Nordic countries than in the EU average (8\%) (Eurostat, 2018). In this same age group (not shown in Figure 1), among employed and unemployed adults with a maximum of lower secondary education (ISCED 02), participation rates were from 2-3 times (Finland, Iceland, Norway) to 5-6 times (Denmark, Sweden) higher in the Nordic countries than the EU average (2.1\%) (Eurostat, 2018). 
Against the above, we expect that we will find relative high participation rates also in this study, with little variation between the four countries.

\section{Individual and work-related factors explain participation in job-related $L L L$}

We have selected the individual and job-related drivers of participation based on previous studies on learning motivation, human capital and workplace learning. Table 1 presents the selected drivers with a literature overview showing evidence of their effects and related theoretical underpinnings. Inversely, these same factors can operate as barriers to participation. However, the existing evidence of these drivers and barriers is limited when it comes to our target group of low-educated, older employees in the four Nordic countries.

Thus, the findings may contribute to new knowledge about the extent to which the factors also apply to better understanding their participation.

\section{[Table 1. Approximately here]}

Dispositional barriers, such as motivation and abilities, tend to be major issues among this group of employees (e.g., Boeren et al., 2010; Brown \& Bimrose, 2018). Besides dispositional, we have analysed the effects of situational, individual factors (e.g., cultural capital, income, learning attitudes, health, and basic skills) as well as of situational and institutional job-related factors (e.g., company size, position, working time, sector, jobsatisfaction, and work autonomy), including skills use at work (Table 1). When it comes to skills use at work, it is an important aspect of skills maintenance and development, based on the 'use it or lose it' hypothesis and on the fact that skills underutilization is also a widespread phenomenon in current working life (Desjardins \& Warnke, 2012; OECD, 2013).

Apart from similarities in the participation rates and the institutional context in the Nordic countries, we know little of how similar or different the individual and job-related drivers of participation are among low-educated, mature-aged employees. It would be logical 
to expect to also find some similarity in them. New knowledge about the drivers of participation could potentially give further indications on the effects of the Nordic support measures and thereby help to develop them further.

\section{Methodology}

\section{Data and the sample}

The data used in this study are from the first round of Survey of Adult Skills, known as PIAAC (Programme for the International Assessment of Adult Competencies) by OECD (2013). PIAAC is a continuation of the previous adult education surveys by OECD: the International Adult Literacy Survey (IALS, 1994-1998) and the Adult Literacy and Lifeskills (ALL) Survey (2003-2008). The PIAAC data were collected with stratified random sampling, in face-to-face computer-assisted tests and interviews of around 166.000 adults, aged 16-64 years, from 24 countries (first round) between August 2011 and March 2012.

Our sample consists of adults with low-education (i.e., max. ISCED 3C, i.e., less than 2 years of upper secondary education), aged 45-64 years, employed (12 months prior to the survey), and living in Denmark, Finland, Norway or Sweden. In this age group, the overall proportion of adults with low education in these countries varied between 19-26\% against the EU28-average $31.3 \%$ in 2012 (Eurostat, 2018). The resulting sample size was $n=1172$ (419, 215, 288 and 250 for Denmark, Finland, Norway and Sweden, respectively). The surveyweighted share of women in the sample $(45.3 \%)$ was slightly lower than that of men, especially in Finland (40\%) (Table 2, all figures are calculated using the survey weights to account for the unequal probability sampling design and reduce possible bias due to non-response).

\section{Measures}

\section{Dependent variable}


The main response variable in the analysis is participation (yes/no) in job-related lifelong learning (LLL), defined as participation in formal or non-formal AET [adult education or training] for job-related reasons in 12 months preceding survey. Participation in formal AET included taking studies in schools, colleges, universities or other education institutions that were work related. Non-formal AET included open or distance learning courses, organized learning activities for on-the-job training or training by supervisors or co-workers (planned periods of training, instruction or practical experience), seminars or workshops, and courses and private lessons.

\section{Independent variables}

The independent variables were the demographic variables of age and gender, as well as individual characteristics, including basic skills (literacy, numeracy and problem solving in technology-rich environments), and job-related characteristics, including skills use at work (described below). We used age classified into 5-year intervals: 45-49, 50-54, 55-59, and 60-64 years.

Basic skills in PIAAC comprise an assessment of proficiency - "a continuum of ability involving the mastery of information-processing tasks of increasing complexity" (OECD, 2016a, 62) - in three key information processing skills domains. Results are represented on a 500-point scale. Literacy refers to "understanding, evaluating, using and engaging with written texts to participate in society, to achieve one's goals, and to develop one's knowledge and potential" (ibid., p. 18), defined in terms of reading of written texts. Numeracy, refers to "the ability to access, use, interpret and communicate mathematical information and ideas, in order to engage in and manage the mathematical demands of a range of situations in adult life" (ibid., p. 22). Problem-solving in technology-rich environments refers to "using digital technology, communication tools and networks to acquire and evaluate information, communicate with others and perform practical tasks" (ibid., p. 28), the assessment of which 
was computed-based. The literacy and numeracy assessments were carried out either as computer-based or paper-based, and the results showed no systematic differences between these two types of scores after controlling for socio-demographic factors (age, educational attainment, immigrant background and gender) (ibid., p. 62).

Other individual characteristics included in the analysis were cultural capital, income, learning attitudes, and health. Cultural capital was measured with parents' (or guardians') highest education level and the number of books at the respondent's home. The former was categorized into two levels (less than secondary $=1$ and at least secondary $=2$ ), since in our sample there were few cases whose parents had tertiary education (or higher). Number of books had five categories ( $1=10$ or less, $2=11-50,3=51-250,4=251-1000,5=1000+)$. Income was measured as the respondent's annual net earnings before taxes and deductions, categorized into quintiles (Cummins, et al., 2015). Learning attitudes were measured with a PIAAC-index, also categorized into quintiles, derived from a set of six questions about learning motivation and strategies (OECD, 2015), higher values indicating more positive attitudes. Health was measured on a 5-point scale (excellent, very good, good, fair, and poor), based on self-assessments.

We used six indicators of job-related characteristics: company size, position, working time, sector, job-satisfaction and work autonomy. Company size was measured with the number of employees $(1=1-10,2=11-50,3=51-250,4=251-1000,5=1000+)$. Working time was measured as number of weekly hours. To distinguish different levels of work engagement, we classified the number of working hours into three categories: $1=0-35$ hours, $2=36-44$ hours, and $3=45$ hours or more. Job position was based on the International Standard Classification of Occupations (ISCO), recoded into a dichotomy with managers vs. others. Self-employment was treated as a separate variable $(1=$ self-employed, $0=$ other $)$. The job-sector variable separated employees in public and private sector. Job satisfaction was 
measured on a 5-point Likert-scale ( $1=$ extremely satisfied, $2=$ satisfied, $3=$ neither satisfied nor dissatisfied, 4=dissatisfied, 5=extremely dissatisfied). For work autonomy, we used an index derived from four variables describing task discretion at work, also categorized into quintiles, with higher values indicating more autonomy.

To create an overall measure for the use of skills at work, we computed a principal component (average $=0$ in the whole data) of the variables measuring reading, writing and complex problem solving at work. To measure the match/mismatch between individual's skills and qualifications with those required by one's job, we used two PIAAC measures of mismatch (OECD, 2013). The first was skills mismatch based on the literacy skills, categorized into under-skilled, over-skilled and matching. The second was qualifications mismatch, indicating the match between one's education and that demanded by the job, categorized as over-educated, under-educated, and matching. Since our data consisted of loweducated people only, there were few over-qualified persons. These were combined with category 'matching'. Thus, in the analyses the variable was used as a dichotomy of being under-educated $(=1)$ or not $(=0)$. Sample means and percentage distributions of the independent variables by country are shown in Table 2 .

[Table 2. Approximately here]

\section{Data analysis}

In the data analysis, we followed the usual methodological principles of large-scale assessment studies. In particular, survey weighting (Stapleton, 2014) and variance estimation by replication methods (Rust, 2014) as well as plausible values (Mislevy, 1991; Wu, 2005) for the proficiency variables were employed. Basic descriptive statistics, like means and percentages, were calculated at country level and in various subgroups, defined by the background variables, within countries. Percentages in the text are rounded to the nearest 
whole percentage. In the computations, we used specific SAS macros provided by the PIAAC Consortium for analyses of PIAAC data.

Our data analysis was exploratory, within the above selection of potential independent variables. Effects of basic skills and other independent variables on the participation in LLL were analyzed using binary multiple logistic regression models fitted to pooled four-country data. First, all independent variables (Table 2) were included together in the model as explanatory variables. The starting model also contained country main effect (i.e., country-specific intercept), as well as the two-way interactions of country and all other explanatory variables. The interactions were used to examine whether the effects of explanatory variables differ significantly between the countries. Due to varying scales, all interval explanatory variables were standardized to z-scores for the logistic regression analysis.

Second, the explanatory variables for the final model were selected by a backward elimination approach. Step by step, we removed the non-significant interactions and main effects until there were only statistically significant $(p<0.05)$ effects left in the model. Since many of the chosen independent variables tend to be correlated, we paid special attention to potential multicollinearity in variable selection. Thus, we consistently examined the estimated regression coefficients during the modelling process, in light of our subject-matter knowledge. Variables, which showed obvious overlap or interference with other variables' regression coefficients, were analysed carefully. Consequently, variables with least statistical power or more missing data were dropped out at early stages of the modelling process.

If there was a significant interaction between a background variable and country, we followed the well-established model-building practice, also keeping the respective main effects in the model, whether they were significant or not. This allows calculating valid country-specific regression coefficients when interactions are present. 
If a background variable shows no significant interaction with country (i.e., it has a main effect only) in the pooled four-country data, its regression coefficient can be considered the same in every country. For this kind of variables, we estimated a common coefficient for all four countries in the final model of the pooled data. For a background variable, which had a significant interaction with country, we calculated country-specific regression coefficients as a sum of the estimated country-specific interaction parameter and the main effect parameter estimate (common for all four countries).

\section{Results}

\section{Participation in job-related $L L L$}

In total, $36 \%$ of the low-educated workers had participated in formal or non-formal adult education for job-related reasons during the last 12 months (Table 3), ranging from 32\% in Finland to 39\% in Denmark. Participation rates were some 10-13 percentage units higher among females than males in all countries but Finland, where they were the same (Table 3). Gender difference was statistically significant in Sweden $(\mathrm{p}<.05)$; notably, it was a trend in Denmark and Norway ( $<<.10$ in both).

\section{[Table 3. Approximately here]}

On the country level, participation in LLL was significantly related to age only in Norway $(\mathrm{p}<.01)$, and the relationship was negative (Figure 2) (in the cross-country analyses the effect of age appeared no longer significant). In addition, in Norway the difference between the youngest (51\% had participated) and oldest (26\%) age group was the largest (25 percentage units).

[Figure 2. Approximately here] 
Participation varied also by other individual and job-related characteristics. Table A1 (Appendix) shows the participation rates in the subgroups of the independent variables. There was a clear bivariate relationship between participation in LLL and almost all the independent variables on an aggregated Nordic level (Table A1). Examples are skills use at work, job position and sector. More than half (57\%) of the low-educated employees, who used their basic skills actively, had participated in LLL, but less than a fourth (24\%) of those, who used these skills least. (Table A1). Further, half (51\%) of the managers had participated, compared to only a quarter (26\%) of the self-employed. Finally, compared to private sector, loweducated workers, employees working in public sector had participated more actively, the overall difference being almost 20 percentage points (Table A1).

When comparing the bivariate associations across the four Nordic countries, we found some striking differences (Table A1). For instance, in Finland the association between participation and being under-skilled in literacy was the opposite (very high participation) of that in Denmark and Norway (low participation). The relationship between participation and cultural capital was only notable in Sweden.

In explaining participation in LLL, bivariate associations are only indicative. Thus, we investigated the role of the independent variables further using multiple logistic regression analysis.

\section{The drivers of participation in LLL more similar than different between the Nordic countries among low-educated adults}

The logistic regression model for the pooled four-country data, where backward elimination was used to select the relevant explanatory variables, suggested that most of the independent variables were not statistically significant in explaining variation of mature, low-educated employees' participation in job-related LLL. Furthermore, there were few statistically 
significant interaction effects between country and explanatory variables, suggesting that the effects of several independent variables are presumably similar in the four countries.

The tests of interaction revealed significant cross-country differences only in regards to parents' education $(p<0.05)$ and being under-skilled (skills mismatch) $(p<0.05)$. Table 4 shows the statistically significant effects (Wald $\chi^{2}$ test). In further analyses, main effects of the variables with significant interactions were kept in the final model, whether they were significant or not. In the final model, there are still some explanatory variables, which are associated with each other (a potential multicollinearity issue), e.g., gender and job sector. Nevertheless, the parameter estimation results (Table 5) are logical and sensible.

[Table 4. Approximately here]

All significant effects in the model were work-related, except gender and income (Table 4). Of all the independent variables (Table 2), significant predictors in all four Nordic countries were gender $(\mathrm{p}<0.01)$, income $(\mathrm{p}<0.001)$, sector $(\mathrm{p}<0.001)$, and skills use at work $(\mathrm{p}<0.001)$. That is, in all four countries, having a higher income, working in the public sector, using their skills a lot at work, and being a woman, increase the likelihood of participation (ceteris paribus). The model explained approximately a fourth (Nagelkerke $\mathrm{R}^{2}=24 \%$ ) of the total variation in participation in the four-country data.

The parameter estimates provide a more detailed picture of the effects of the independent variables in the model. They are presented in Table 5. Recall (see section Data Analysis), if an independent variable has a significant interaction effect with country, the model produces a country-specific regression coefficient for it, calculated as a sum of the interaction parameter and the respective 'overall' main effect, which is common to all four countries. Otherwise (i.e., no interaction with country), the regression coefficient is equal in all countries. In our model, only the coefficients of parents' education and being under-skilled vary between countries. 


\section{[Table 5. Approximately here]}

Gender, income, job sector and skills use at work did not show significant interaction effect with country (thus, they have a common regression coefficient in each country, Table 5). Of these variables, the strongest predictor of participation was job sector (public) with odds ratio $(\mathrm{OR})$ of 2.3 , followed by male gender $(\mathrm{OR}=0.56$, inverted $\mathrm{OR}=1.8)$. For income and the skills use at work, an increase of one standard deviation increases the odds of participation by 1.6 .

We found two statistically significant differences between the countries. However, some caution is warranted when interpreting them, as both of them can be incidental, due to somewhat low number of observations. Parental education had a large positive effect on participation in Sweden $(\mathrm{OR}=3.7)$, and being under-skilled had a very large positive effect in Finland (OR no less than 9.8) (Table 5). Further investigations of these findings revealed that only $16 \%$ of the parents of the low-educated Swedish employees in our data had secondary education, and the proportion of the Finnish respondents, who are under-skilled with respect to their work, was only $4 \%$ in the data. Combined with relatively small national sample sizes of low-educated employees (Table 2), this means that the above findings are based on rather small number of observations. This may explain the strikingly large effects found in the data. However, compared to findings from previous studies (Table 1), the findings as such are not unrealistic, but rather could be expected. Why these effects were not found in other countries is a question we shall come back to in the discussion.

To assess the explanatory power of the model in each country, we calculated approximate country-specific R-squares by fitting the independent variables of the fourcountry model to each country's data separately. The results showed that the variables explained approximately a third of the variation in participation in Finland (Nagelkerke 
$\mathrm{R}^{2}=34 \%$ ), a quarter in Sweden (26\%) and Norway (25\%), while somewhat less in Denmark $(18 \%)$ (Table 5).

\section{Discussion}

This study explored drivers of participation in organized, formal and non-formal job-related LLL among low-educated, mature-aged employees, and compared them between four Nordic countries. Overall, the findings showed that the participation rates were relatively high, and the countries appeared more similar than different in regards the drivers of participation. The factors that appeared as significant drivers in all countries were gender, income, job sector and skills use at work. Only two of the drivers were different between the countries: parents' education and being under-skilled, the first in Sweden only and the second in Finland only. These six factors explained a quarter of the variation in participation, countries modelled together, but varied somewhat across the countries.

Compared to other sub-populations of low-educated adults in other countries (see Desjardins, 2015 and OECD, 2013), the participation rate of $36 \%$ can be considered relatively high. Thus, the findings can be taken as an indication of a relative success of the Nordic policies and the opportunities and support that employers provide to learning and development for low-educated, mature-aged employees. Low-educated, older adults seem at least reasonably motivated in investing in their own learning and skills development. Likewise, their employers seem to be willing to provide opportunities to support their learning. Nevertheless, when the corresponding participation rate for a similar sample but with tertiary education is twice as high, $73 \%$ (Ref. removed for anonymity), a reasonable conclusion is that there are still major barriers to participation by this population in the Nordic region. Clearly, targeted Nordic lifelong learning policies as well as strengthening the incentive mechanisms for employers to encourage their further investments in skills development of low-educated employees are not only needed, but necessary (OECD, 2016b). 
In all of the four countries, significant drivers of participation were more similar than different: high income, frequent skills use at work, working in the public sector, and being a female (in order of importance), increase the likelihood of participation (ceteris paribus) among low-educated older adults. As participation in LLL varies considerably by occupational sector (Kans, et al., 2016), it is likely that these factors reflect certain types of work over others, such as better-paid work in female-dominated, public sector occupations, where employees frequently need to use their skills. The public sector is large in the Nordic region - represented by about $30 \%$ of employees in our data (Table 2). Their strong investments in digitalization (e.g., in health-care and education, suffering from shortage of qualified labour), as well as in "smart government", may have given a boost to investing in developing digital skills, for example. On another note, it is interesting that income seems to remain a major issue for participation in the target population, regardless of the employers' support and long-term availability of low-cost training opportunities in these countries. In conclusion, the findings confirm the results from earlier studies, pointing out the large differences in learning opportunities - in availability and quality - between jobs and enterprises (Rubensjon \& Desjardin, 2009; Zanazzi, 2018). This is an area where employers and management are key players, ensuring that design of job tasks contribute to learning-rich forms of work and work environment, for all employees.

It was only in two regards that the four countries' drivers of participation were different. Firstly, as Sweden has a long held status as an example of an egalitarian society, with generally high education level, it was highly unexpected that parents' education (cultural background) appeared a significant driver of participation. This is likely to reflect Sweden's highest proportion of parents with education below upper secondary level (84\%, Table 2$)$ in our data. Secondly, a very interesting question is, why being under-skilled was a significant driver among low-educated, mature employees only in Finland? The question is particularly 
intriguing because in Finland, the proportion of under-skilled was the lowest among the countries (4\%, Table 2$)$. This question cannot be answered based on our analyses, but it should be investigated further in future studies.

Even if the drivers of participation were more similar than different across the four countries, the explanatory power (R-squared) of the final models differed between them. Our theoretical background does not allow for explaining these differences, but these betweencountry differences in explained variation can be related to the different, relatively small sample sizes; R-squares computed from small data sets can be prone to random variation. Another explanation may be related to the selection of the independent variables: disregarding the cultural-institutional context of the evidence from previous studies may have resulted in relationships of varying strength in different countries. We did not base our choice of evidence from previous findings of factors with effect on participation only on Nordic studies. For some variables the evidence may have been from one but not all of the Nordic countries; for others, the evidence may have been based on countries outside the Nordic welfare regime. Interestingly, most of the independent variables appeared non-significant in the final model. For age, the findings were unexpected, against the established strong negative ageparticipation relationship, almost invariably. However, considering the target group, this is a remarkable finding. It may further imply that the Nordic policies and measures, general and targeted, have an impact, as suggested by the Bounded Agency Model (Rubenson \& Desjardins, 2009), helping atypical learners and vulnerable groups to overcome various situational and institutional barriers. As such, the latter are not different from those in other countries, although institutional barriers in them are low, across occupational positions (Roosmaa \& Saar, 2017). On another note, the finding may further speak on behalf of the greater relevance of the job-tasks for learning participation than, for example, for age. As for the other non-significant factors, the findings suggest that, in order to better understand the 
participation in LLL among low-educated older employees in the Nordic countries, future studies need to explore connections to other factors, possibly also those not previously included in participation studies. Similar to the discussion of the country differences in the explanatory power of the models, this finding may also imply that rather than building further participation research on assumed universal factors with effect, a more institutional contextsensitive approach may be needed to advance our understanding of the topic.

A limitation to this study was the small data, especially the relatively small sample size per country. As the statistical power of interaction tests is weaker than that of tests of main effects, more data would have been required to find statistical significance of the (multiple) interaction terms. Thus, a larger data set may have resulted in more differences between the countries. However, with the data used, the interactions of the selected variables with country were not even close to being significant, besides the two interactions found. This means that a lot more data would have been needed to find significant differences between the countries as a function of the independent variables. Therefore, our findings should be taken as indicative, and they should be tested in future studies. The latter should also explore further the effect of occupational sector. 


\section{References}

Ajzen, I., \& Fishbein, M. (1980). Understanding attitudes and predicting social behavior. Englewood Cliffs, N. J.: Prentice Hall.

Aldridge, F., \& Hughes, D. (2012). NIACE Adult Participation in Learning Survey. Leicester: National Institute of Adult Continuing Education (England and Wales).

Andreasson, U. (2018). In the shadow of happiness. Copenhagen: Nordic Council of Ministers.

Antikainen, A. (2010). The capitalist state and education. The case of restructuring the Nordic model. Current Sociology, 58(4), 530-550.

Becker Patterson, M. (2018). The Forgotten 90\%: Adult Nonparticipation in Education. Adult Education Quarterly, 68(1), 41-62.

Billett, S. (2001). Learning through working life: Interdependencies at work. Studies in Continuing Education, 23(1), 19-35.

Blossfield, H-P., Kilpi-Jakonen, E., Vono de Vilhena, D., \& Buchholz, S. (Eds.) (2014). Adult learning in modern societies. An international comparison from a life-course perspective. Cheltenham: Edgar Elgar.

Blossing, U., Imsen, G., \& Moos, L. (Eds.) (2014). The Nordic education model. 'A school for all' encounters neo-liberal policy. Dordrecht: Springer.

Boeren, E. (2017). Understanding adult lifelong learning participation as a layered problem. Studies in Continuing Education, 39(2), 161-175.

Boeren, E, \& Holford, J. (2016). Vocationalism varies (a lot): A 12-country multivariate analysis of participation in formal adult learning. Adult Education Quarterly, 66(2), 120-142

Boeren, E., Nicaise, I., \& Baert, H. (2010). Theoretical models of participation in adult education - the need for an integrated model. International Journal of Lifelong Learning, 29(1), 45-61. 
Booth, M. (2014). The almost nearly perfect people behind the myth of the Scandinavian utopia. London: Jonathan Cape.

Brown, A. \& Bimrose, J. (2018). Drivers of learning for the low-skilled. International Journal of Lifelong Education, 37(2), 151-167, DOI: 10.1080/02601370.2017.1378934

Cedefop (2018). Insights into skill shortages and skill mismatch: learning from Cedefop's European skills and jobs survey. Luxembourg: Publications Office. Cedefop reference series; No 106.

Cedefop (2015). Unequal access to job-related learning: evidence from the adult education survey. Luxembourg: Publications Office. Cedefop research paper; No 52. http://dx.doi.org/10.2801/219228

Cincinnato, S., De Wever, B., Van Keer, H., \& Valcke, M. (2016). The influence of social background on participation in adult education: Applying the cultural capital framework. Adult Education Quarterly, 66(2), 143-168.

Cort, P., Mariager-Anderson, K., \& Thomsen, R. (2018). Busting the myth of low-skilled workers - destabilizing EU LLL policies through the life stories of Danes in low-skilled jobs. International Journal of Lifelong Education, 37(2), 199-215.

Cross, K.P. (1981). Adults as Learners. Increasing participation and facilitating learning. San Francisco: Jossey-Bass.

Cummins, P. A., Kunkel, S. R., \& Walker, R. M. (2015). Adult Education and Training Programs for Older Adults in the U.S.: National Results and Cross-National Comparisons Using PIAAC Data. Retrieved 06.09.2015, from http://miamioh.edu/cas/academics/centers/scripps/research/publications/2015/.

DeFilippi, R. J., \& Arthur, M. B. (1994). The Boundaryless career: A competency-based perspective. Journal of Organizational Behavior, 15(4), 307-324. 
DeGrip, A., \& Van Loo, J. (2002). The economics of skills obsolescence: A review. In A. DeGrip, J. VanLoo \& K. Mayhew (Eds.), Understanding skills obsolescence. Research in Labour Economics, 21, 1-26.

Desjardins, R. (2015). Participation in Adult Education Opportunities: Evidence from PIAAC and policy trends in selected countries. Background paper for the Education for All Global Monitoring Report 2015. Retrieved 7.7.2018 from https://cloudfront.escholarship.org/dist/prd/content/qt1k1203tn/qt1k1203tn.pdf.

Desjardins, R., \& K. Rubenson (2011). An analysis of skill mismatch using direct measures of skills. OECD Education Working Papers, No. 63. Paris: OECD Publishing.

Desjardins, R., \& A. Warnke (2012). Ageing and skills: A review and analysis of skill gain and skill loss over the lifespan and over time. OECD Education Working Papers, No. 72, Paris: OECD.

Dieckhoff, M., Jungblut, J.-M., \& O’Connell, P. J. (2007). Job-related training in Europe: Do institutions matter? In D. Gallie (Ed.) Employment regimes and the quality of work (pp.77-104) New York: Oxford University Press.

Dämmrich, J., Vono de Vilhena, D., \& Reichart, E. (2014). Participation in adult learning in Europe: The impact of country-level and individual characteristics. In H-P. Blossfield, E. Kilpi-Jakonen, D. Vono de Vilhena, \& S. Buchholz (Eds.) Adult learning in modern societies. An international comparison from a life-course perspective (pp. 29-55). Cheltenham: Edgar Elgar.

Engeström, Y. (2001). Expansive learning at work: Towards an activity-theoretical reconceptualisation. Journal of Education and Work, 14(1), 133-156.

Esping-Andersen, G. (1989). The three political economies of the welfare state. Canadian Review of Sociology and Anthropology, 26, pp. 10-36.

Eurofound (2012). The 5th European Working Conditions Survey: Overview report. 
Luxembourg: Publications Office of the European Union.

European Commission (2018). The 2018 Ageing Report Economic and Budgetary Projections for the EU Member States (2016-2070). Luxembourg: Publications Office of the European Union.

Eurostat (2018). Analyses carried out for this article by the author, based on the Eurostat open databases, available at http://ec.europa.eu/eurostat/data/database.

Fouarge, D., \& Schils, T. (2009). The effect of early retirement incentives on the training participation of older workers. Review of Labour Economics and Industrial Relations, 23(1), 85-109.

Fouarge, D., Schils, T., \& de Grip, A. (2013). Why do low-educated workers invest less in further training?, Applied Economics, 45(18), 2587-2601.

Georgellis, Y., \& Lange, T. (2009). Participation in continuous, on-the-job training and the impact on job satisfaction: longitudinal evidence from the German labour market. International Journal of Human Resource Management, 18(6), 969-985.

Gorard, S., Rees, G., \& Fevre, R. (1999). Patterns of participation in lifelong learning: do families make a difference? British Educational Research Journal, 25(4), 517-532. Heckman, J. J. (2006). Skills formation and the economics of investing in disadvantaged children. Science 312:1900-1902.

Hodgson, G. F. (2018). What the world can learn about equality from the Nordic model. The Conversation, July 30, 2018.

Iqbal, R., \& Todi, P. (2015). The Nordic Model: existence, emergence and sustainability. Procedia Economics and Finance, 30, pp. $336-351$.

Kans, K., Christoffels, I., Schipperheyn, R., Groeneveld, M. J., Cuppen, J., \& Hofland, A. (2016). Lifelong learning: an occupational perspective. 's-Hertogenbosch: ECBO. 
Kyndt, E., Govaerts, N., Dochy, F., \& Baert, H. (2011). The learning intention of lowqualified employees: A key for participation in lifelong learning and continuous training. Vocations and Learning, 4(3), 211-229.

Lavrijsen, J. \& Nicaise, I. (2017). Systemic obstacles to lifelong learning: the influence of the educational system design on learning attitudes. Studies in Continuing Education, 39(2), 176-196.

Massing, N. \& Gauly, B. (2017). Training participation and gender: Analyzing individual barriers across different welfare state regimes. Adult Education Quarterly, 67(4), 266-285.

Maurer, T. J. (2002). Employee Learning and development orientation: Toward an integrative model of involvement in continuous learning. Human Resources Development Review, 1(1), 9-44.

Mellander, E. \& Flemming Anderssen, A. (2015). An overview of the characteristics of the Nordic region. In T. Fridberg, A. Rosdahl, V. Halapuu, A. et al. (Eds.). Adult skills in the Nordic region: Key information-processing skills among adults in the Nordic region (pp. 3952). Copenhagen: Nordic Council of Ministers.

Mellander, E., Flemming Anderssen, A., \& Sønnesyn, J. (2015). Key InformationProcessing Skills in the Nordic Region Compared to the Non-Nordic EU Countries and NonNordic \& Non-EU Countries. In T. Fridberg, A. Rosdahl, V. Halapuu, et al. (Eds.). Adult skills in the Nordic region: Key information-processing skills among adults in the Nordic region (pp. 53-82). Copenhagen: Nordic Council of Ministers.

Mislevy, R. (1991). Randomization-based inference about latent variables from complex samples. Psychometrika, 56, 188-196.

NordForsk (2017). Education for Tomorrow - phase I. Key findings. Copenhagen: NordForsk. 
OECD (2016a). The Survey of Adult Skills: Reader's Companion (2 ${ }^{\text {nd }}$. Edition), OECD Skills Studies. Paris: OECD Publishing.

OECD (2016b). Skills Matter: Further Results from the Survey of Adult Skills. OECD Skills Studies. Paris: OECD Publishing.

OECD (2015). Codebook for derived variables for PIAAC public database.

http://www.oecd.org/skill/piaac/codebook\%2520for\%2520DVs\%25203 16\%2520March\%25 202015.docx\&usg=AOvVaw1vKSz8Rgr1yaHk_T5OT32q Retrieved 15.03.2018.

OECD (2013). OECD skills outlook. First results from the Survey of Adult Skills. Paris: OECD Publishing.

Roosmaa, E.-L., \& Saar, E. (2017) Adults who do not want to participate in learning: a cross-national European analysis of their perceived barriers. International Journal of Lifelong Education, 36(3), 254-277.

Rosdahl, A. (2015). Adult education and training. In T. Fridberg, A. Rosdahl, V. Halapuu, et al. (Eds.). Adult skills in the Nordic region: Key information-processing skills among adults in the Nordic region (pp. 183-202). Copenhagen: Nordic Council of Ministers.

Rothes, A., Lemos, M. S., \& Gonçalves, T. (2017). Motivational profiles of adult learners. Adult Education Quarterly, 67(1), 3-29.

Rubenson, K. (2006). The Nordic model of lifelong learning. Compare: A Journal of Comparative and International Education, 36(3), 327-341.

Rubenson, K., \& Desjardins, R. (2009). The impact of welfare state regimes on barriers to participation in adult education: A bounded agency model. Adult Education Quarterly, 59(3), 187-207.

Russ-Eft, D. (2002). A typology of training design and work environment factors affecting workplace learning and transfer. Human Resources Development Review, 1(1), 4565. 
Rust, K. (2014). Sampling, weighting, and variance estimation in international large-scale assessments. In L. Rutkowski, M. von Davier, \& D. Rutkowski, (Eds.). Handbook of International Large-Scale Assessments. Background, Technical Issues and Methods of Data Analysis (pp. 117-154). Boca Raton, FL: CRC Press.

Sanders, J., Oomens, S., Blonk, R. W. B., \& Hazelzet, A. (2011). Explaining lower educated workers' training intentions. Journal of Workplace Learning, 23(6), 402-416.

Sandlin, J. A., Wright, R. R., \& Clark, C. (2011). Reexamining theories of adult learning and adult development through the lenses of public pedagogy. Adult Education Quarterly, 63(1), 3-23.

Scott, J. (2000). Rational choice theory. In G. Browning, A. Halcli, \& F. Webster (Eds.). Understanding Contemporary Society: Theories of the Present (pp. 126-138). London: Sage.

Stapleton, L.M. (2014). Incorporating sampling weights into single- and multilevel analyses. In L. Rutkowski, M. von Davier, \& D. Rutkowski, (Eds.). Handbook of International Large-Scale Assessments. Background, Technical Issues and Methods of Data Analysis (pp. 363-388). Boca Raton, FL: CRC Press.

Swanson, R. A. (2001). Human resources development and its underlying theory. Human Resources Development International, 4(4), 299-312.

Tuijnman, A. (1991). Lifelong education: A test of the accumulation hypothesis. International Journal of Lifelong Education, 10 (4), 275-285.

UNESCO (2016a). Paper commissioned for the Global Education Monitoring Report 2016, Education for people and planet: Creating sustainable futures for all. Retrieved 08.10.2018 from http://unesdoc.unesco.org/images/0024/002456/245626E.pdf

UNESCO (2016b). Recommendation on adult learning and education. Retrieved 28.6.2018 from http://unesdoc.unesco.org/images/0024/002451/245179e.pdf. 
Verhofstadt, E., \& Omey, E. (2003). The impact of education on job satisfaction in the first job. University of Gent Working Paper 2003/169, March. Retrieved 7.7.2015 from http://citeseerx.ist.psu.edu/viewdoc/download?doi=10.1.1.195.5928\&rep=rep1\&type=pdf.

Vinther-Jørgensen, T., Armangué, L., Andersen, T. J., Lauridsen, S., Mogensen, M., Rishede Philipsen, M. \& Høxbroe Jeppesen, L. (2013). Uddannelse for voksne. [Education for adults] TemaNord 2013:575. Copenhagen: Nordic Council of Ministers.

Vono de Vilhena, D. Kilpi-Jakonen, E., Schurer, S., \& Blossfield, H.-P. (2014). The promise and reality of adult learning in modern societies. In H-P. Blossfield, E. KilpiJakonen, D. Vono de Vilhena, \& S. Buchholz (Eds.) Adult learning in modern societies. An international comparison from a life-course perspective (pp. 351-374). Cheltenham: Edgar Elgar.

White, P. (2012). Modeling the 'learning divide': Predicting participation in adult learning and future learning intentions, 2002-2010. British Educational Research Journal, (38)1, 153-175.

$\mathrm{Wu}, \mathrm{M}$. (2005). The role of plausible values in large-scale surveys. Studies in Educational Evaluation, 31, 114-128.

Zanazzi, S. (2018). Investing in skills to overcome the crisis? Low-skilled workers in Italy: European strategies, policies and structural weaknesses. International Journal of Lifelong Education, 37(2), 216-233. 
Table 1

Selected drivers of participation and a literature overview showing evidence of their effects and related theoretical underpinnings

\begin{tabular}{|c|c|}
\hline Factor & Effect on participation and theoretical underpinnings \\
\hline $\begin{array}{r}\text { Demographic } \\
\text { Age } \\
\text { Gender }\end{array}$ & $\begin{array}{l}\text { An inverse relationship (e.g., Aldridge \& Hughes, 2012; Boeren, Nicaise \& Baert, } \\
\text { 2010; Rosdahl, 2015; ref. removed for anonymity) - low net return of investments } \\
\text { (ROI) (Fouarge \& Schils, 2009) } \\
\text { Women participate more in the Nordic countries, men in most other countries } \\
\text { (Massing \& Gauly, 2017), gender-segregated labour market, females with less } \\
\text { learning opportunities at work (Georgellis \& Lange, 2009) }\end{array}$ \\
\hline $\begin{array}{l}\text { Individual } \\
\text { Learning attitudes }\end{array}$ & $\begin{array}{l}\text { Positive relationship, strong predictor (Boeren et al., 2010; Maurer, 2002; ref. } \\
\text { removed for anonymity; White, 2012), among low-educated/low-skilled often related } \\
\text { to prior learning experiences (Brown \& Bimrose, 2018) and intertwined with learning } \\
\text { opportunities, job autonomy, economic preferences, and personality traits (Fouarge, } \\
\text { Schils \& de Grip, 2013; Kyndt, Govaerts, Dochy \& Baert, 2011; Sanders, et al., 2011) } \\
\text { - theory of reasoned action by Ajzen \& Fishbein, 1980) }\end{array}$ \\
\hline $\begin{array}{r}\text { Income } \\
\text { Job satisfaction } \\
\text { Health }\end{array}$ & $\begin{array}{l}\text { Income, a motivator or a barrier for the low-skilled (Massing \& Gauly, 2017). Job } \\
\text { satisfaction, and health positively associated with participation (Eurofound, 2012; } \\
\text { Verhofstadt \& Omey, 2003). - Motivation theories (e.g., Maslow's) and the rational } \\
\text { choice theory (Scott, 2000); situational factors, to an extent (Russ-Eft, 2002) }\end{array}$ \\
\hline Cultural capital & $\begin{array}{l}\text { Positive effect (Gorard, Rees, \& Fevre, 1999; Heckman, 2006; Zanazzi, 2018) - } \\
\text { accumulation theory (Tuijnman, 1991); theory of cultural reproduction (Bourdieu) - } \\
\text { but research inconclusive, as adults' learning opportunities, motivation and identity } \\
\text { may weight more (Cincinnato, et al., 2016; Gorard et al., } 1998 \text { - quoted in White, } \\
\text { 2012) }\end{array}$ \\
\hline $\begin{array}{l}\text { Human capital, } \\
\text { Basic skills }\end{array}$ & $\begin{array}{l}\text { Positive effect (literacy, numeracy, problem-solving in technology rich environment): } \\
\text { low-educated workers have lower skills and low participation (OECD, 2013) - but in } \\
\text { the Nordic countries limited or no importance (Rosdahl, 2015; ref. removed for } \\
\text { anonymity) }\end{array}$ \\
\hline $\begin{array}{r}\text { Work-related } \\
\text { Job position } \\
\text { Company size } \\
\text { Working time } \\
\text { Work autonomy } \\
\text { Sector }\end{array}$ & $\begin{array}{l}\text { Higher participation among managerials (White, 2012), in large firms, and full-time } \\
\text { work (Dieckhoff, et al., 2007). Work overload a barrier (Massing \& Gauly, 2017; } \\
\text { Russ-Eft, 2002); workers with more autonomy are likely to also take more } \\
\text { responsibility for their own learning (OECD, 2013). Participation across sectors varies } \\
\text { (Kans, et al., 2016), with a gender x sector effect: women work more in public sector, } \\
\text { men in industry; strong unions can have positive effect (Dieckhoff, et al., 2007). }\end{array}$ \\
\hline $\begin{array}{r}\text { Skills use at work } \\
\text { Skills mismatch } \\
\text { Qualifications } \\
\text { mismatch } \\
\end{array}$ & $\begin{array}{l}\text { Positive effect: 'use it or lose it' and the 'intellectual challenge' hypotheses } \\
\text { (Desjardins \& Warnke, 2012; OECD, 2013) - Workers in a deficit mismatch situation } \\
\text { likely to participate in employer financed training (Desjardins \& Rubenson, 2011); } \\
\text { Skills- and competence shortage affects positively, especially among low-skilled } \\
\text { (Brown \& Bimrose, 2018). }\end{array}$ \\
\hline
\end{tabular}


Table 2

Weighted distributions/averages of the background variables in the PIAAC sample by country

\begin{tabular}{|c|c|c|c|c|c|c|}
\hline \multicolumn{2}{|l|}{ Variable } & \multirow{2}{*}{$\begin{array}{c}\begin{array}{c}\text { Denmark } \\
\mathrm{n}=419\end{array} \\
49,3\end{array}$} & \multirow{2}{*}{$\begin{array}{c}\begin{array}{c}\text { Finland } \\
\mathrm{n}=215\end{array} \\
40,4\end{array}$} & \multirow{2}{*}{$\begin{array}{c}\begin{array}{c}\text { Norway } \\
\mathrm{n}=288\end{array} \\
47,1\end{array}$} & \multirow{2}{*}{$\begin{array}{c}\begin{array}{c}\text { Sweden } \\
n=250\end{array} \\
44,1\end{array}$} & \multirow{2}{*}{$\begin{array}{c}\begin{array}{c}\text { All } \\
n=1172\end{array} \\
45,3\end{array}$} \\
\hline Gender $(\%)$ & Females & & & & & \\
\hline Age $(\%)$ & $\begin{array}{l}45-49 \text { years } \\
50-54 \text { years } \\
55-59 \text { years } \\
60-65 \text { years }\end{array}$ & $\begin{array}{l}23,7 \\
33,5 \\
25,9 \\
16,8\end{array}$ & $\begin{array}{l}14,4 \\
25,3 \\
35,5 \\
24,8\end{array}$ & $\begin{array}{l}24,3 \\
28,2 \\
24,4 \\
23,1\end{array}$ & $\begin{array}{l}17,3 \\
29,7 \\
23,7 \\
29,2\end{array}$ & $\begin{array}{l}19,8 \\
29,5 \\
26,2 \\
24,4\end{array}$ \\
\hline \multicolumn{2}{|l|}{ Literacy proficiency (mean) } & 243 & 256 & 258 & 248 & 251 \\
\hline \multicolumn{2}{|l|}{ Numeracy proficiency (mean) } & 253 & 253 & 258 & 246 & 252 \\
\hline \multicolumn{2}{|c|}{$\begin{array}{l}\text { Proficiency in problem-solving } \\
\text { in technology rich environments (mean) }\end{array}$} & 249 & 246 & 254 & 243 & 248 \\
\hline \multicolumn{2}{|l|}{ Learning attitudes (mean) } & 2,8 & 3,1 & 2,8 & 3,1 & 3,0 \\
\hline $\begin{array}{l}\text { Cultural capital } \\
\text { Parents' education (\%) }\end{array}$ & $\begin{array}{l}<\text { upper secondary } \\
\geq \text { upper secondary }\end{array}$ & $\begin{array}{l}62,4 \\
37,6\end{array}$ & $\begin{array}{l}78,2 \\
21,8\end{array}$ & $\begin{array}{l}59,7 \\
40,3\end{array}$ & $\begin{array}{l}83,6 \\
16,4\end{array}$ & $\begin{array}{l}74,4 \\
27,6\end{array}$ \\
\hline \multicolumn{2}{|r|}{$\begin{array}{l}<11 \\
11-25 \\
26-100 \\
101-200 \\
201-500 \\
500+\end{array}$} & $\begin{array}{c}18,7 \\
19,2 \\
34,4 \\
19,7 \\
5,3 \\
2,8\end{array}$ & $\begin{array}{c}17,3 \\
27,2 \\
36,1 \\
10,3 \\
6,2 \\
2,9\end{array}$ & $\begin{array}{c}10,8 \\
15,9 \\
36,3 \\
23,3 \\
8,3 \\
5,4\end{array}$ & $\begin{array}{c}13,0 \\
13,7 \\
44,6 \\
17,4 \\
8,9 \\
2,4\end{array}$ & $\begin{array}{c}14,4 \\
17,6 \\
39,2 \\
18,1 \\
7,5 \\
3,3\end{array}$ \\
\hline \multicolumn{2}{|l|}{ Income quintile (mean) } & 2,7 & 2,7 & 2,6 & 2,6 & 2,6 \\
\hline \multicolumn{2}{|l|}{ Job satisfaction (mean) } & 4,4 & 4,1 & 4,3 & 4,3 & 4,3 \\
\hline Health & $\begin{array}{l}\text { Excellent } \\
\text { Very good } \\
\text { Good } \\
\text { Fair } \\
\text { Poor }\end{array}$ & $\begin{array}{c}13,1 \\
42,0 \\
23,3 \\
16,3 \\
5,3\end{array}$ & $\begin{array}{c}9,6 \\
15,2 \\
44,8 \\
28,3 \\
19,9\end{array}$ & $\begin{array}{c}11,9 \\
29,7 \\
37,0 \\
17,9 \\
2,9\end{array}$ & $\begin{array}{l}21,1 \\
27,7 \\
28,3 \\
19,9 \\
2,9\end{array}$ & $\begin{array}{c}15,5 \\
29,3 \\
31,8 \\
20,0 \\
3,5\end{array}$ \\
\hline Job position & $\begin{array}{l}\text { Manager (\%) } \\
\text { Self-employed (\%) }\end{array}$ & $\begin{array}{l}13,4 \\
10,0\end{array}$ & $\begin{array}{l}13,4 \\
19,7\end{array}$ & $\begin{array}{l}21,6 \\
10,8\end{array}$ & $\begin{array}{l}18,5 \\
16,2\end{array}$ & $\begin{array}{l}17,3 \\
14,2\end{array}$ \\
\hline Company size (\%) & $\begin{array}{l}1-10 \\
11-50 \\
51-250 \\
251-1000 \\
1000+\end{array}$ & $\begin{array}{c}32,4 \\
30,8 \\
21,7 \\
9,9 \\
5,2\end{array}$ & $\begin{array}{c}47,5 \\
22,3 \\
16,8 \\
7,1 \\
6,3\end{array}$ & $\begin{array}{c}35,4 \\
31,0 \\
19,0 \\
8,3 \\
4,7\end{array}$ & $\begin{array}{c}40,8 \\
26,1 \\
19,8 \\
8,6 \\
4,7\end{array}$ & $\begin{array}{c}38,7 \\
27,6 \\
19,6 \\
8,6 \\
5,4\end{array}$ \\
\hline \multicolumn{2}{|l|}{ Working time (mean) } & $\begin{array}{l}36,4 \\
33,4\end{array}$ & $\begin{array}{l}40,5 \\
37,8\end{array}$ & $\begin{array}{l}35,9 \\
32,3\end{array}$ & $\begin{array}{l}39,0 \\
35,3\end{array}$ & $\begin{array}{l}38,0 \\
34,5\end{array}$ \\
\hline $\begin{array}{l}\text { Work autonomy (mea } \\
\text { Sector }\end{array}$ & Public (\%) & $\begin{array}{c}3,3 \\
32,9\end{array}$ & $\begin{array}{c}3,1 \\
18,3\end{array}$ & $\begin{array}{c}3,1 \\
20,5\end{array}$ & $\begin{array}{c}3,5 \\
35,4\end{array}$ & $\begin{array}{c}3,3 \\
28,8\end{array}$ \\
\hline \multicolumn{2}{|l|}{ Skills use at work (mean) } & $-0,0$ & $-1,2$ & 0,2 & 0,4 & 0,0 \\
\hline Skills (literacy) mismatch (\%) & $\begin{array}{l}\text { Under-skilled } \\
\text { Over-skilled }\end{array}$ & $\begin{array}{l}5,3 \\
8,1\end{array}$ & $\begin{array}{l}4,2 \\
5,1\end{array}$ & $\begin{array}{c}7,8 \\
31,8\end{array}$ & $\begin{array}{l}26,1 \\
19,3\end{array}$ & $\begin{array}{l}14,2 \\
17,0\end{array}$ \\
\hline \multicolumn{2}{|c|}{ Qualifications mismatch (\%) Under-educated } & 29,3 & 49,8 & 46,8 & 53,7 & 46,2 \\
\hline
\end{tabular}


Table 3

Participation rates in LLL by gender and country among low-educated workers (\%)

\begin{tabular}{cccccc}
\hline Gender & Denmark & Finland & Norway & Sweden & All \\
\hline Females & 43,4 & 32,0 & 41,3 & 43,4 & 40,0 \\
Males & 34,9 & 32,1 & 31,7 & 30,0 & 32,2 \\
\hline All & 39,1 & 32,1 & 36,2 & 35,8 & 36,1 \\
\hline
\end{tabular}


Table 4

Statistically significant effects on participation in LLL according to multiple logistic regression analysis of the pooled four-country data

\begin{tabular}{|c|c|c|c|}
\hline Factor & DF & Wald $\chi^{2}$ & $\mathrm{p}$ value \\
\hline Country & 3 & 3.91 & 0.272 \\
\hline Gender (male) & 1 & 8.94 & $0.003 * *$ \\
\hline \multicolumn{4}{|l|}{ Individual characteristics } \\
\hline Parents' education & 1 & 2.42 & 0.120 \\
\hline Income(quintile) & 1 & 25.78 & $<0.001 * * *$ \\
\hline Interaction Country*Parents' education & 3 & 8.10 & $0.044^{*}$ \\
\hline \multicolumn{4}{|l|}{ Job-related characteristics } \\
\hline Sector (public) & 1 & 18.09 & $<0.001 * * *$ \\
\hline \multicolumn{4}{|l|}{ Skills use at work } \\
\hline Skills use at work & 1 & 25.60 & $<0.001 * * *$ \\
\hline Under-skilled & 1 & 0.59 & 0.442 \\
\hline Interaction Country*Under-skilled & 3 & 9.72 & $0.021^{*}$ \\
\hline
\end{tabular}

Table 5

Multiple logistic regression model on participation in $L L L$ in the four Nordic countries: regression coefficients (B), their standard errors (SE) and the corresponding odds ratios

\begin{tabular}{|c|c|c|c|c|c|c|c|c|c|c|c|c|}
\hline \multirow[b]{2}{*}{ Factor } & \multicolumn{3}{|c|}{$\begin{array}{r}\text { Denmark } \\
(n=273)\end{array}$} & \multicolumn{3}{|c|}{$\begin{array}{l}\text { Finland } \\
(n=124)\end{array}$} & \multicolumn{3}{|c|}{$\begin{array}{l}\text { Norway } \\
(n=232)\end{array}$} & \multicolumn{3}{|c|}{$\begin{array}{l}\text { Sweden } \\
(\mathrm{n}=164)\end{array}$} \\
\hline & $\mathrm{B}$ & $\mathrm{SE}$ & OR & $\mathrm{B}$ & SE & OR & $\mathrm{B}$ & SE & OR & B & SE & OR \\
\hline Country intercept & .19 & .48 & & -.75 & .61 & & -.81 & .47 & & -1.68 & .67 & \\
\hline Gender (male) & $-.59 * *$ & .22 & .56 & $-.59 * *$ & .22 & .56 & $-.59 * *$ & .22 & .56 & $-.59 * *$ & .22 & .56 \\
\hline \multicolumn{13}{|l|}{$\begin{array}{l}\text { Individual } \\
\text { characteristics }\end{array}$} \\
\hline Parents' education & -.40 & .33 & .67 & .17 & .45 & 1.19 & .20 & .29 & 1.22 & $1.30 *$ & .53 & 3.68 \\
\hline Income (quintile) & $.47 * * *$ & .10 & 1.60 & $.47 * * *$ & .10 & 1.60 & $.47 * * *$ & .10 & 1.60 & $.47 * * *$ & .10 & 1.60 \\
\hline \multicolumn{13}{|l|}{$\begin{array}{l}\text { Job-related } \\
\text { characteristics }\end{array}$} \\
\hline Sector (public) & $.85 * * *$ & .23 & 2.34 & $.85 * * *$ & .23 & 2.34 & $.85 * * *$ & .23 & 2.34 & $.85 * * *$ & .23 & 2.34 \\
\hline \multicolumn{13}{|l|}{ Skills use at work } \\
\hline Skills use at work & $.46 * * *$ & .10 & 1.58 & $.46 * * *$ & .10 & 1.58 & $.46 * * *$ & .10 & 1.58 & $.46 * * *$ & .10 & 1.58 \\
\hline Under-skilled & .13 & .71 & 1.14 & $2.28^{*}$ & .96 & 9.79 & -.66 & .61 & .51 & -.64 & .45 & .53 \\
\hline $\mathrm{R}^{2}$ (Nagelkerke) & .18 & & & .34 & & & .25 & & & .26 & & \\
\hline
\end{tabular}




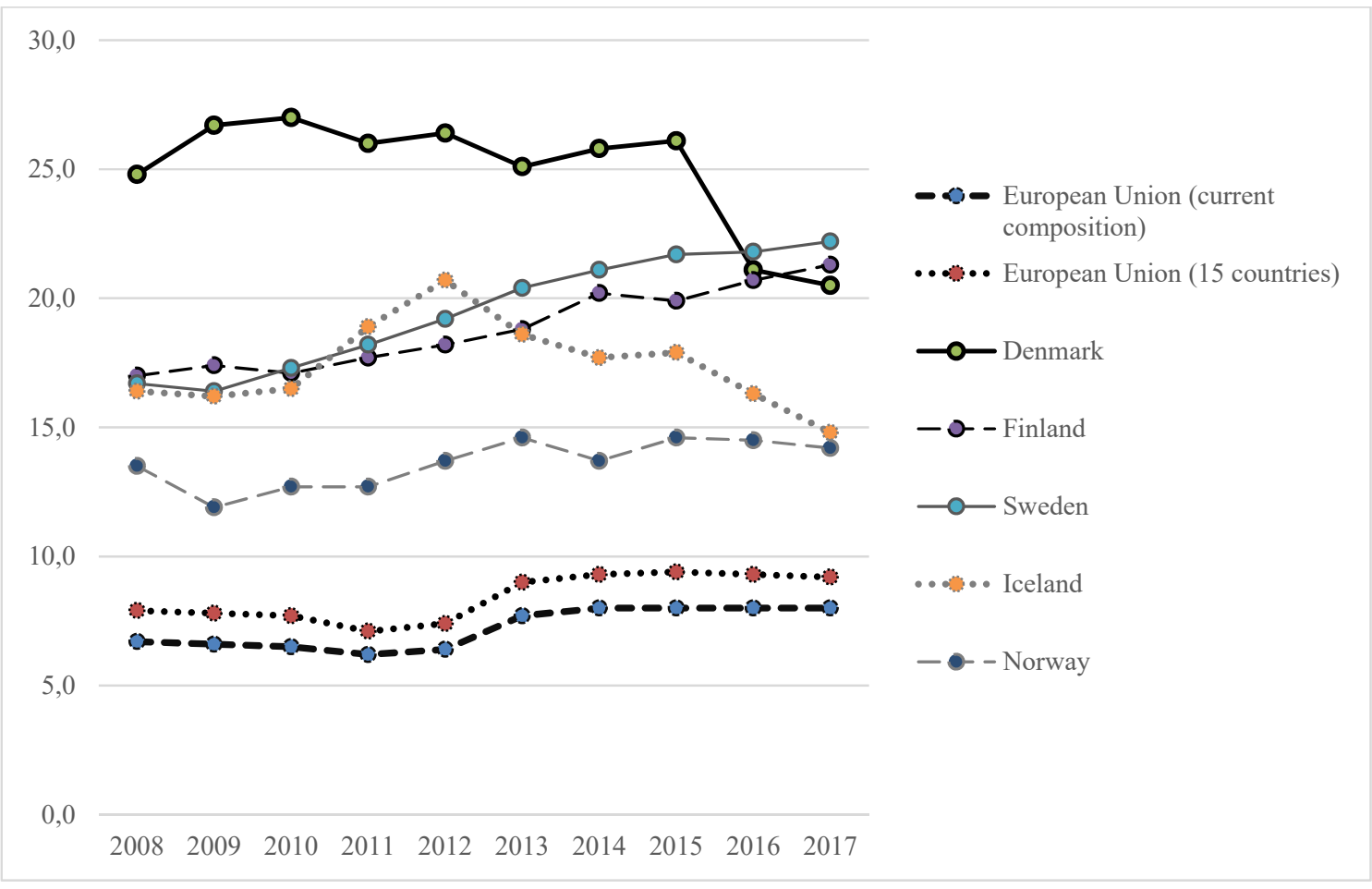

Figure 1. Participation in formal and non-formal education and training in 2008-2017 in the EU and the Nordic countries among employed adults aged 55-74 years (Source: Author's analysis based on EUROSTAT online database) 


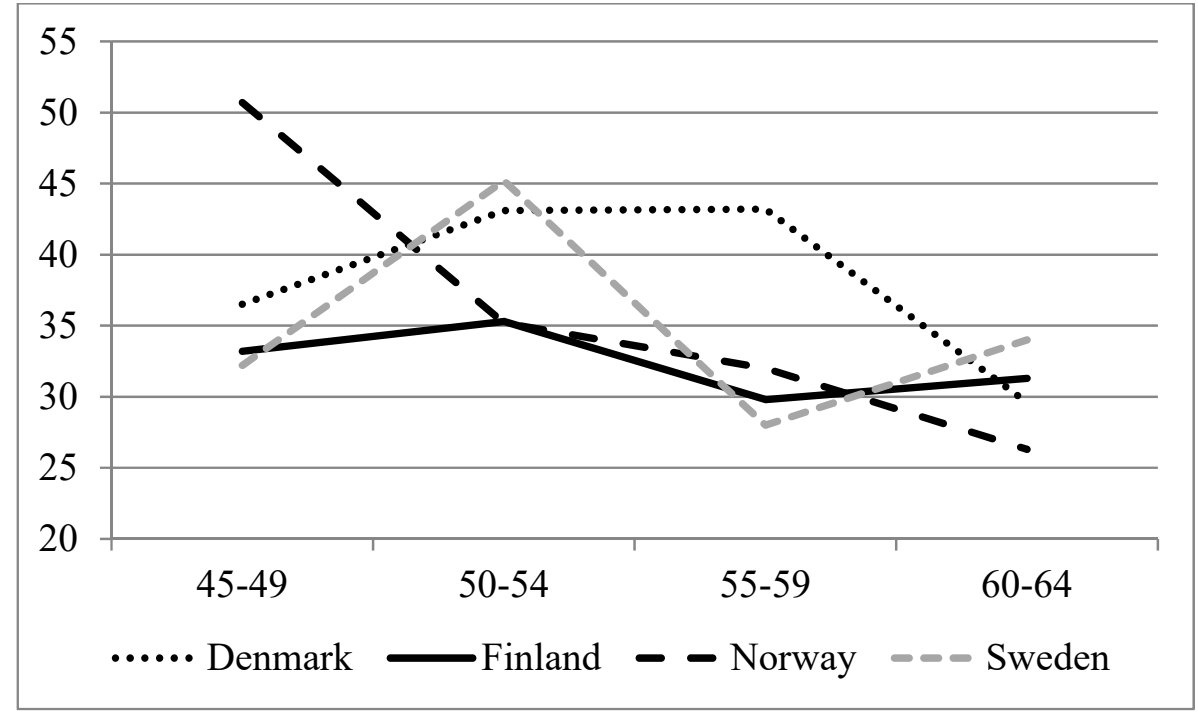

Figure 2. Participation rates by age-group and country (\%) 


\section{Appendix}

\section{Table A1}

Participation rates in LLL by background variables and country among low-educated workers $(\%)^{2}$

\begin{tabular}{|c|c|c|c|c|c|}
\hline & Denmark & Finland & Norway & Sweden & All \\
\hline Literacy level 1 & 28,9 & 24,8 & 27,3 & 32,3 & 29,6 \\
\hline Literacy level 2 & 40,4 & 32,9 & 35,2 & 37,1 & 36,7 \\
\hline Literacy level > 2 & 50,9 & 36,5 & 41,8 & 36,8 & 40,9 \\
\hline Numeracy level 1 & 32,1 & 26,6 & 30,2 & 29,3 & 29,7 \\
\hline Numeracy level 2 & 33,0 & 34,8 & 37,3 & 36,9 & 35,9 \\
\hline Numeracy level > 2 & 52,9 & 31,0 & 37,2 & 40,2 & 41,2 \\
\hline Problem solving level $<1$ & 28,4 & 28,6 & 29,2 & 31,1 & 29,7 \\
\hline Problem solving level 1 & 56,4 & 45,0 & 39,0 & 44,1 & 45,6 \\
\hline Problem solving level > 1 & 47,7 & 34,8 & 61,4 & 39,3 & 48,5 \\
\hline Learning attitude poor & 25,7 & 19,9 & 30,9 & 34,6 & 29,5 \\
\hline Learning attitude medium & 45,8 & 36,7 & 42,9 & 32,1 & 37,9 \\
\hline Learning attitude good & 53,5 & 39,1 & 39,9 & 39,0 & 41,9 \\
\hline Parents' education $<$ upper secondary & 40,3 & 32,2 & 32,6 & 32,6 & 34,0 \\
\hline Parents' education $\geq$ upper secondary & 38,0 & 32,2 & 39,8 & 59,7 & 42,8 \\
\hline Number of books at home $\leq 25$ & 36,3 & 30,6 & 28,9 & 22,1 & 29,0 \\
\hline Number of books at home $26-200$ & 41,2 & 35,2 & 40,6 & 37,9 & 38,9 \\
\hline Number of books at home $>200$ & 37,0 & 24,3 & 31,5 & 60,3 & 42,9 \\
\hline Income quintiles $1-2$ & 33,2 & 20,6 & 28,1 & 33,0 & 30,2 \\
\hline Income quintile 3 & 38,6 & 42,2 & 37,6 & 42,6 & 40,2 \\
\hline Income quintiles $4-5$ & 48,6 & 41,1 & 51,0 & 41,7 & 45,2 \\
\hline Job satisfaction low & 31,5 & 22,7 & 25,0 & 22,1 & 24,3 \\
\hline Job satisfaction medium & 34,6 & 30,9 & 33,5 & 34,9 & 33,6 \\
\hline Job satisfaction high & 43,4 & 40,0 & 41,1 & 40,8 & 41,5 \\
\hline Health poor or fair & 33,2 & 30,8 & 28,0 & 25,9 & 28,8 \\
\hline Health good & 27,6 & 35,3 & 34,9 & 37,6 & 34,8 \\
\hline Health very good or excellent & 46,0 & 27,4 & 41,6 & 39,2 & 40,5 \\
\hline Manager & 35,1 & 61,5 & 53,2 & 52,5 & 50,8 \\
\hline Employee & 43,1 & 28,6 & 33,2 & 32,4 & 34,6 \\
\hline Self-employed & 18,3 & 25,3 & 19,5 & 30,8 & 25,7 \\
\hline Company size $1-50$ & 37,1 & 28,1 & 30,6 & 34,8 & 33,2 \\
\hline Company size $51-250$ & 33,6 & 35,3 & 41,4 & 36,6 & 36,8 \\
\hline Company size $>250$ & 55,4 & 40,2 & 50,8 & 42,2 & 47,0 \\
\hline Working time $0-35$ hours & 41,2 & 26,0 & 28,1 & 29,0 & 31,3 \\
\hline Working time $36-44$ hours & 40,2 & 33,7 & 42,2 & 37,6 & 38,5 \\
\hline Working time $>44$ hours & 31,8 & 34,5 & 36,0 & 39,6 & 36,5 \\
\hline Work autonomy low & 39,6 & 33,5 & 38,3 & 29,1 & 34,4 \\
\hline Work autonomy medium & 44,7 & 29,0 & 38,9 & 28,1 & 34,0 \\
\hline Work autonomy high & 37,6 & 32,5 & 33,7 & 41,6 & 37,8 \\
\hline Private sector & 29,3 & 30,0 & 31,5 & 31,4 & 30,7 \\
\hline Public sector & 60,2 & 42,2 & 56,6 & 44,0 & 49,8 \\
\hline Skills use at work lowest quartile & 29,4 & 22,5 & 15,6 & 26,3 & 23,8 \\
\hline Skills use at work 2nd quartile & 41,6 & 23,2 & 29,6 & 36,3 & 33,6 \\
\hline Skills use at work 3rd quartile & 40,1 & 45,8 & 52,4 & 43,0 & 45,1 \\
\hline Skills use at work highest quartile & 63,7 & 58,0 & 46,3 & 59,2 & 56,6 \\
\hline Under-skilled in literacy & 24,0 & 86,0 & 13,8 & 34,2 & 34,0 \\
\hline Matching literacy skills & 39,2 & 31,0 & 35,9 & 37,2 & 36,3 \\
\hline Over-skilled in literacy & 44,5 & 23,7 & 52,2 & 39,1 & 44,2 \\
\hline
\end{tabular}

\footnotetext{
${ }^{2}$ To make this table more economic and readable, we categorized continuous variables and, for some variables, we merged some original categories. In actual statistical analyses and modelling we used the original values and categories. This may cause seeming inconsistencies between this table and results of logistic regression analyses.
} 


\begin{tabular}{lccccc}
\hline Under-educated & 56,3 & 35,2 & 47,1 & 45,0 & 45,4 \\
Not under-educated & 34,7 & 34,8 & 27,3 & 21,8 & 27,9 \\
\hline
\end{tabular}

